\title{
E2F Promoter-Regulated Oncolytic Adenovirus with p16 Gene Induces Cell Apoptosis and Exerts Antitumor Effect on Gastric Cancer
}

\author{
Juming Ma $\cdot$ Xiaoping He $\cdot$ Weiguo Wang $\cdot$ Yao Huang $\cdot$ \\ Lin Chen · Wenming Cong · Jianzhong Gu · Huizhen Hu • \\ Jianguo Shi $\cdot$ Linfang $\mathrm{Li} \cdot$ Changqing Su
}

Published online: 8 May 2009

(C) Springer Science+Business Media, LLC 2009

\section{Erratum to: Dig Dis Sci}

DOI 10.1007/s10620-008-0543-0

In order to facilitate online searching, the initials of author names that appeared in the original article have been spelled out in this erratum.

Juming Ma and Xiaoping He contributed equally to this work.

The online version of the original article can be found under doi: 10.1007/s10620-008-0543-0.

J. Ma $\cdot$ W. Wang $\cdot$ H. Hu $\cdot$ J. Shi

Department of Internal Medicine, 117 Hospital of Chinese

People's Liberation Army, Hangzhou,

People's Republic of China

X. He

Department of Gastroenterology, Jinling Hospital, Nanjing,

People's Republic of China

Y. Huang $\cdot$ L. Chen $\cdot$ W. Cong $\cdot$ L. Li $\cdot$ C. Su $(\bowtie)$

Laboratory of Gene \& Viral Therapy, Eastern Hepatobiliary

Surgical Hospital, Second Military Medical University,

Shanghai, People's Republic of China

e-mail: suchangqing@gmail.com

J. Gu

Shanghai SLAC Laboratory Animal Co. Ltd., Chinese Academy

of Sciences - Shanghai Branch, Shanghai 200031, China 